\title{
Pengukuran Kecerahan Langit Arah Zenit di Medan dan Serdang Bedagai Menggunakan Sky Quality Meter
}

\author{
Abu Yazid Raisal ${ }^{1 *}$, Hariyadi Putraga ${ }^{2}$, Muhammad Hidayat ${ }^{3}$ dan Arwin Juli Rakhmadi ${ }^{4}$ \\ 1,2,3,4 Universitas Muhammadiyah Sumatera Utara \\ Jalan Denai No 217, Medan, Sumatera Utara \\ *E-mail: abuyazidraisal@gmail.com
}

\begin{abstract}
Abstrak
Polusi cahaya merupakan masalah yang dialami seluruh dunia yang berdampak pada berkurangnya bintang yang dapat dilihat pada malam hari. Penelitian ini bertujuan untuk mengukur kecerahan langit arah zenit untuk meminimalkan pengaruh polusi cahaya dalam melakukan pengamatan benda langit. Penelitian dilakukan dengan metode observasi tingkat kecerahan langit dengan Sky Quality Meter (SQM). Pengukuran kecerahan langit dilakukan pada dua tempat, yaitu di Medan dan Serdang Bedagai. SQM dipasang ke arah zenit dan diatur untuk mengambil data setiap dua detik. Pengamatan dilakukan pada tanggal 10-13 November 2018 yaitu pada saat fase bulan baru. Nilai rata-rata kecerahan langit yang diperoleh di Medan sebesar 18,05 mpsas dan nilai NELM sebesar 4,00. Berdasarkan skala Bortle, Medan termasuk daerah kelas kesembilan yaitu inner-city sky. Sementara, nilai rata-rata kecerahan langit yang diperoleh di Serdang Bedagai sebesar 19,69 mpsas dan nilai NELM sebesar 5,26. Berdasarkan skala Bortle, Serdang Bedagai termasuk daerah kelas keenam yaitu bright suburban sky.
\end{abstract}

Kata kunci: Sky Quality Meter, polusi cahaya, skala Bortle.

\begin{abstract}
Light pollution is a worldwide problem that affects fewer stars that can be seen at night. This study aims to measure the brightness of the sky in the zenith direction to minimize the effect of light pollution in observing celestial bodies. The research used the observation method of sky brightness level with SQM. Measurement of sky brightness was carried out in two places, namely in Medan and Serdang Bedagai. The SQM is mounted in a zenith direction and set to retrieve data every two seconds. Observations were made on November 10-13, 2018, during the new moon phase. The average value of sky brightness obtained in Medan is 18.05 mpsas and the NELM value is 4.00. Based on the Bortle scale, Medan is included in the ninth class area, namely the inner-city sky. Meanwhile, the average value of sky brightness obtained in Serdang Bedagai is 19.69 mpsas and the NELM value is 5.26. Based on the Bortle scale, Serdang Bedagai belongs to the sixth class area, namely bright suburban sky.
\end{abstract}

Keywords: Sky Quality Meter, light pollution, Bortle scale

\section{PENDAHULUAN}

Polusi cahaya merupakan problematika yang dialami seluruh dunia. Tidak hanya perkotaan tetapi keseluruhan daerah yang terang saat malam hari, kebanyakan berasal dari cahaya artifisial. Tingkat polusi cahaya juga bisa semakin bertambah dengan adanya cahaya Bulan di langit malam. Polusi cahaya mempunyai efek negatif yang dapat mempengaruhi kehidupan di Bumi, termasuk
Astronomi, ekologi dan kesehatan manusia (Lyytimäki et al., 2012). Sumber terbesar dari polusi cahaya berasal dari lampu jalan. Sumber lainnya berupa cahaya lampu komersial, cahaya dari daerah perkotaan, lampu penerangan di taman, dan cahaya dari lampu di luar ruangan yang berhamburan hingga ke atas. Polusi cahaya berpengaruh terhadap kecerahan langit yang berdampak pada berkurangnya bintang yang dapat dilihat pada malam hari (Rajkhowa, 2014). Selain polusi cahaya ada beberapa faktor yang dapat 
mempengaruhi kecerahan langit yaitu cahaya galaksi, cahaya bintang, cahaya zodiak, airglow malam, cahaya emisi, dan fase bulan (Raisal et al., 2017).

Kecerahan langit dapat diukur menggunakan Sky Quality Meter (SQM). SQM merupakan sebuah fotometer berukuran kecil dan berharga rendah yang dapat digunakan untuk mengukur kecerahan langit malam, dimana pengguna dapat dengan mudah dan cepat mendapatkan data kualitas dari langit malam di setiap tempat kapanpun juga (Cinzano, 2005). Terdapat banyak jenis dari SQM yang dapat digunakan sesuai kebutuhan, baik itu menggunakan sumber listrik, baterai, atau USB dari PC komputer.

SQM memiliki medan pandang pengukuran sebesar 20 derajat dan hanya memiliki kesalahan relatif kurang dari 3\% (D Herdiwijaya \& Arumaningtyas, 2011), selain itu resolusi temporal pengambilan data pengamatan dapat dilakukan hingga ke dalam satuan detik waktu. Parameter dan variabel yang diberikan dalam pembacaan SQM adalah tanggal dan waktu universal, tanggal dan waktu lokal, suhu, bilangan, frekuensi, dan nilai kecerahan langit. Kecerahan langit diukur menggunakan satuan magnitudes per square acrsecond (mpsas) (Unihedron, 2020).

SQM dapat digunakan untuk mengukur waktu fase gerhana Bulan dan Matahari (ButarButar et al., 2020) (Yudhiakto Pramudya \& Arkanuddin, 2016). Selain itu SQM juga dapat digunakan untuk menentukan awal waktu salat Subuh (Noor \& Hamdani, 2018).

Langit paling gelap berada pada pagi dini hari (setelah tengah malam) lebih gelap dibandingkan langit malam sebelum tengah malam. Hal ini menunjukkan langit paling gelap berada diantara tengah malam sebelum senja pagi hari dan fluktuasi cahaya di pagi hari lebih stabil dan temperaturnya lebih dingin daripada sebelum tengah malam (Dhani Herdiwijaya, 2016).

Pada langit yang memiliki awan yang sedikit bahkan tidak ada, ketinggian zenit yang dibaca SQM berada pada jarak langit tertinggi yang memendarkan cahaya polusi dari lampu perkotaan. Namun apabila dalam pengambilan data di zenit berawan tebal, maka ketinggian zenit yang dibaca merupakan ketinggian awan yang menangkap cahaya lampu kota sehingga menerangi langit malam seolah berwarna kemerahan dan perubahan warna langit di atasnya akan sulit terbaca dengan medan pandang yang telah dipersempit.

Ambang Batas Pengamatan Mata dikenal dengan istilah Naked Eye Limitting Magnitude (NELM). Dalam keadaan langit tanpa awan, pengamat dapat melihat kecerahan langit malam pada lokasi tertentu. Pengamat juga dapat melihat berbagai pola konstelasi bintang dan kecerlangan langit dengan menggunakan mata telanjang dan mengukur rentang keterlihatan benda astronomis dalam pengamatan menggunakan mata secara langsung.

Kecerahan langit dibagi menjadi sembilan kelas yaitu, excellent dark-sky site, typical truly dark site, sky rural, rural/suburban transition, suburban sky, bright suburban sky, suburban/urban transition, city sky, dan innercity sky. Kesembilan kelas tersebut dikenal dengan skala Bortle (Bortle, 2001). John Bortle membangun sebuah kategori langit malam yang dengan segera populer, memiliki beberapa kelebihan untuk mengestimasi ambang batas keterlihatan. Skala langit gelap Bortle menggunakan deskripsi kualitatif untuk membedakan satu kelas langit dengan kelas langit yang lainnya. Sebagai contoh, untuk dapat melihat berkas Galaksi Andromeda dengan mata telanjang membutuhkan indikator langit pada kelas 6 atau yang lebih baik. Skala ini juga merupakan referensi silang dari NELM yang dapat digunakan untuk deskripsi daerah yang cukup luas dan juga mengintegrasikan faktor yang sama dengan pengamatan langit malam. Tabel 1 menunjukkan skala Bortle dalam ambang batas pengamatan mata (NELM).

Tabel 1. Skala Bortle

\begin{tabular}{ccc}
\hline $\begin{array}{c}\text { Kelas } \\
\text { Bortle }\end{array}$ & NELM & Kategori \\
\hline 1 & $7,5-8,0$ & Excellent dark-sky site \\
2 & $7,0-7,5$ & Typical truly dark site \\
3 & $6,5-7,0$ & Sky rural \\
4 & $6,0-6,5$ & Rural/suburban transition \\
5 & $5,5-6,0$ & Suburban sky \\
6 & $5,0-5,5$ & Bright suburban sky \\
7 & $4,5-5,0$ & Suburban/urban transition \\
8 & $4,0-4,5$ & City sky \\
9 & $<4,0$ & Inner-city sky \\
\hline
\end{tabular}

Penelitian ini bertujuan untuk mengukur kecerahan langit arah zenit untuk meminimalkan pengaruh polusi cahaya dalam melakukan pengamatan benda langit. 
Penelitian ini dilakukan di dua tempat yaitu, Medan dan Serdang Bedagai.

\section{METODE}

Penelitian dilakukan dengan metode observasi tingkat kecerahan langit dengan SQM. Pengukuran kecerlangan langit dilakukan pada dua tempat, yaitu di Observatorium Ilmu Falak Universitas Muhammadiyah Sumatera Utara (OIF UMSU) yang berlokasi di Jalan Denai No 217, Medan. Lokasi ini memiliki tingkat kepadatan populasi tinggi dan memiliki volume cahaya buatan yang banyak berhamburan ke langit. Tempat lain yang diukur adalah di pantai Romantis, kecamatan Pantai Cermin, Serdang Bedagai. Lokasi berada agak sedikit jauh dari lokasi perkotaan dan permukiman penduduk.

Tabel 1. Profil lokasi pengamatan

\begin{tabular}{ccc}
\hline Lokasi & Koordinat & Profil Lokasi \\
\hline OIF & $3^{\circ} 34^{\prime}$ LU, $98^{\circ} 43^{\prime}$ & Perkotaan \\
UMSU & BT & \\
Pantai & $3^{\circ} 35^{\prime}$ LU, $99^{\circ} 05^{\prime}$ & Pedesaan \\
Romantis & BT & \\
\hline
\end{tabular}

Instrumen yang digunakan untuk mengukur kecerahan langit adalah SQM-LU-DL. SQMLU-DL dihubungkan dengan PC menggunakan kabel USB. SQM dipasang ke arah zenit dan terbebas dari gangguan yang dapat menghalangi alat terhadap langit. Pemasangan ke arah zenit juga dilakukan untuk mengurangi pengaruh cahaya dari lampu sekitar terhadap SQM secara langsung (Raisal et al., 2021). SQM diatur untuk mengambil data setiap dua detik. Pengukuran kecerahan langit dilakukan dari tengah malam hingga pukul 05.30 WIB. Hal ini dilakukan untuk mengurangi gangguan cahaya mengingat aktivitas masyarakat berkurang pada saat tengah malam. Dari tiap data dicari nilai kecerahan langit tertinggi/maksimum. Kemudian nilai tersebut diubah kedalam bentuk NELM untuk mengukur rentang keterlihatan benda astronomis dalam pengamatan menggunakan mata secara langsung. Untuk mengubah bentuk mpsas menjadi bentuk NELM menggunakan persamaan 1 .

$$
\mathrm{NELM}=7,93-5 \times \log \left(10^{(4,316-(\text { Bmpsas/5) })}+1\right)
$$

SQM dimasukkan ke dalam tabung pelindung (housing) agar terlindung apabila hujan. Oleh karena itu, nilai yang terbaca oleh SQM akan mengalami sedikit perubahan karena pengaruh housing. Untuk itu, kalibrasi nilai yang terbaca sangat diperlukan. Kalibrasi dilakukan dengan cara mengarahkan SQM ke sumber cahaya yang sama dan mencatat nilai SQM yang terbaca sebelum dimasukkan ke dalam housing dan setelah dimasukkan ke dalam housing.

\section{HASIL DAN PEMBAHASAN}

HASIL

Pada hasil pengamatan langit menggunakan SQM, digunakan nilai offset sebesar -0,22 MPASS sebagai nilai kalibrasi antara instrumen dengan tabung pelindung instrumen yang dipakai. Pengamatan dilakukan pada tanggal 10-13 November 2018 yaitu pada saat fase bulan baru. Hal ini dilakukan untuk menghindari pengaruh dari cahaya Bulan.

Gambar 1 menunjukkan grafik kecerahan langit terhadap waktu di OIF UMSU. Garis warna merah, biru, hijau, dan ungu masing-masing menunjukkan grafik kecerahan langit tanggal 10, 11, 12, dan 13 November 2018. Dari gambar dapat dilihat kecerahan langit tanggal 10 dan 11 November 2018 mempunyai nilai kecerahan langit yang lebih tinggi daripada tanggal 12 dan 13 November 2018.

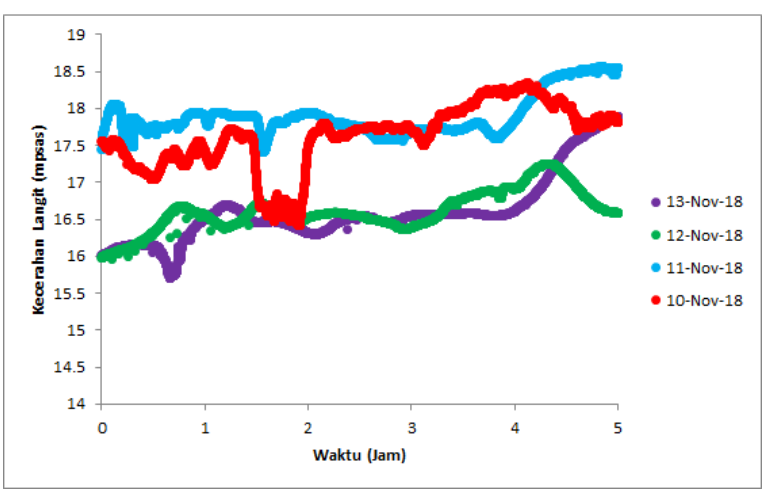

Gambar 1. Grafik kecerahan langit terhadap waktu di OIF UMSU

Dengan menggunakan pendekatan statistik, jumlah data kecerahan langit pada rentang tertentu dapat diketahui. Gambar 2 
menunjukkan jumlah data kecerahan langit pada rentang tertentu pada tanggal 10 November 2018 di OIF UMSU. Data kecerahan langit yang terbaca oleh SQM berada pada rentang 16,41 - 18,34 mpsas. Data kecerahan langit yang paling banyak terbaca oleh SQM berada pada rentang 17,71 - 17,83 mpsas dengan jumlah 1953 data. Total data kecerahan langit yang dikumpulkan sebanyak 9929 data.

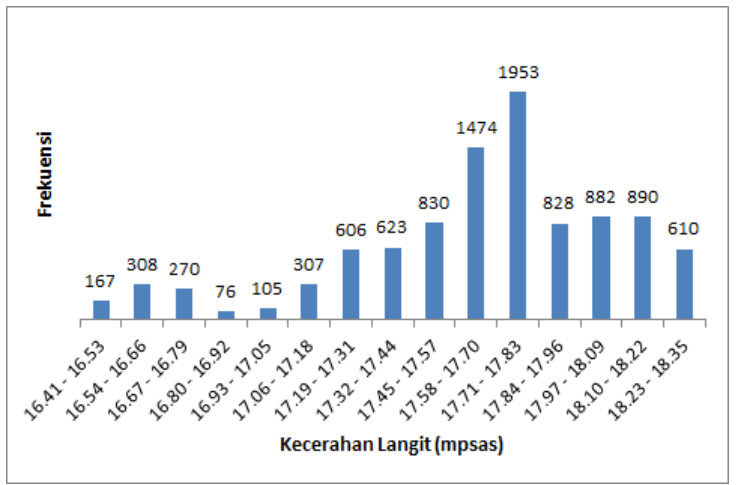

Gambar 2. Jumlah data kecerahan langit pada rentang tertentu pada tanggal 10 November 2018 di OIF UMSU

Gambar 3 menunjukkan jumlah data kecerahan langit pada rentang tertentu pada tanggal 11 November 2018 di OIF UMSU. Data kecerahan langit yang terbaca oleh SQM berada pada rentang 17,38 - 18,65 mpsas. Data kecerahan langit yang paling banyak terbaca oleh SQM berada pada rentang 17,74 - 17,82 mpsas dengan jumlah 2178 data. Total data kecerahan langit yang dikumpulkan sebanyak 9930 data.

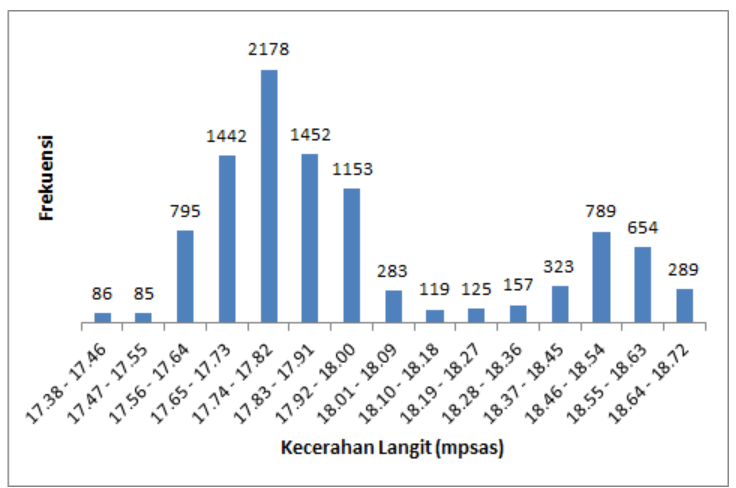

Gambar 3. Jumlah data kecerahan langit pada rentang tertentu pada tanggal 11 November 2018 di OIF UMSU
Gambar 4 menunjukkan jumlah data kecerahan langit pada rentang tertentu pada tanggal 12 November 2018 di OIF UMSU. Data kecerahan langit yang terbaca oleh SQM berada pada rentang 15,96 - 17,25 mpsas. Data kecerahan langit yang paling banyak terbaca oleh SQM berada pada rentang 16,50 $-16,58$ mpsas dengan jumlah 2000 data. Total data kecerahan langit yang dikumpulkan sebanyak 9926 data.

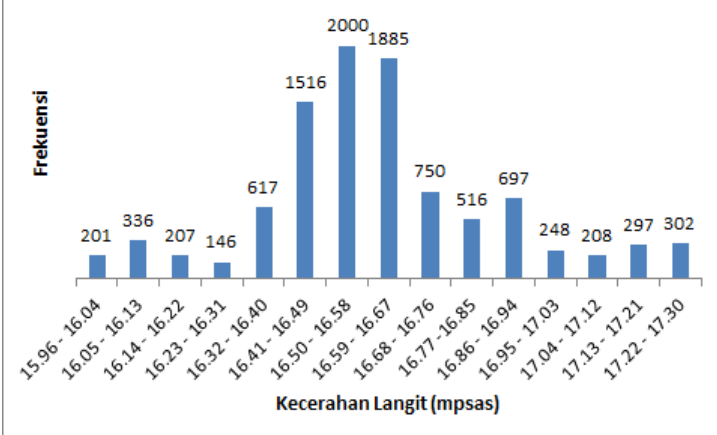

Gambar 4. Jumlah data kecerahan langit pada rentang tertentu pada tanggal 12 November 2018 di OIF UMSU

Gambar 5 menunjukkan jumlah data kecerahan langit pada rentang tertentu pada tanggal 13 November 2018 di OIF UMSU. Data kecerahan langit yang terbaca oleh SQM berada pada rentang 15,70 - 17,97 mpsas. Data kecerahan langit yang paling banyak terbaca oleh SQM berada pada rentang 16,50 $-16,65$ mpsas dengan jumlah 3123 data. Total data kecerahan langit yang dikumpulkan sebanyak 9930 data.

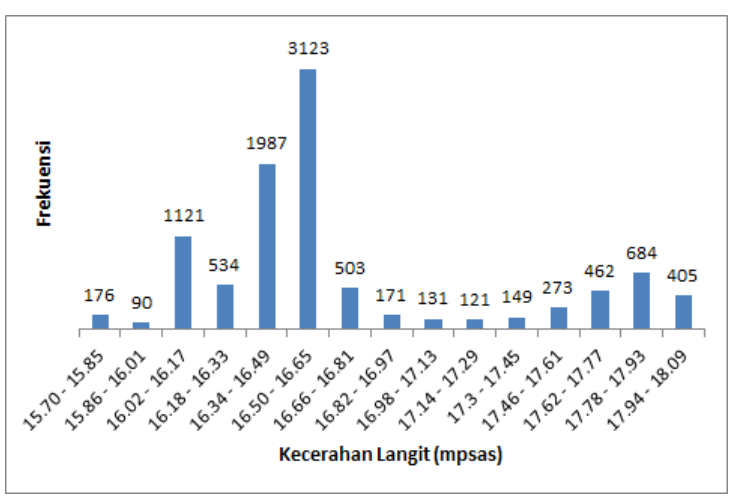

Gambar 5. Jumlah data kecerahan langit pada rentang tertentu pada tanggal 13 November 


\section{8 di OIF UMSU}

Untuk mengukur rentang keterlihatan benda astronomis dalam pengamatan menggunakan mata secara langsung data kecerahan langit diubah ke dalam bentuk NELM. Data kecerahan langit yang diubah ke dalam bentuk NELM adalah data kecerahan langit dengan nilai maksimum. Nilai NELM pada tanggal 10-13 November 2018 di OIF UMSU dapat dilihat pada tabel 2.

Tabel 2. Nilai NELM di OIF UMSU

\begin{tabular}{ccc}
\hline Tanggal & $\begin{array}{c}\text { Kecerahan langit } \\
\text { maksimum (mpsas) }\end{array}$ & NELM \\
\hline $10 / 11 / 18$ & 18,34 & 4.25 \\
$11 / 11 / 18$ & 18,65 & 4.50 \\
$12 / 11 / 18$ & 17,25 & 3.32 \\
$13 / 11 / 18$ & 17,97 & 3.94 \\
\hline Rata-rata & 18,05 & 4.00 \\
\hline
\end{tabular}

Pengambilan data di pantai Romantis tidak dilakukan dari tengah malam. Pengambilan data dilakukan pada saat menjelang terbit fajar. Gambar 6 menunjukkan grafik kecerahan langit terhadap waktu di pantai Romantis. Garis warna merah, hijau, ungu, dan biru masing-masing menunjukkan grafik kecerahan langit tanggal 10,11, 12, dan 13 November 2018. Dari gambar dapat dilihat kecerahan langit tanggal 10 dan 11 November 2018 mempunyai nilai kecerahan langit yang lebih tinggi daripada tanggal 12 dan 13 November 2018.

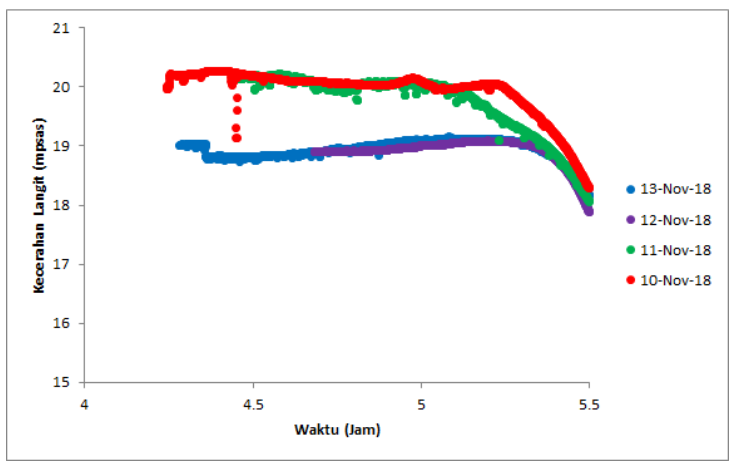

Gambar 6. Grafik kecerahan langit terhadap waktu di pantai Romantis

Gambar 7 menunjukkan jumlah data kecerahan langit pada rentang tertentu pada tanggal 10 november 2018 di pantai Romantis. Data kecerahan langit yang terbaca oleh SQM berada pada rentang 18,11 - 20,27 mpsas. Data kecerahan langit yang paling banyak terbaca oleh SQM berada pada rentang 20,01 $-20,19$ mpsas dengan jumlah 1216 data. Total data kecerahan langit yang dikumpulkan sebanyak 2289 data.

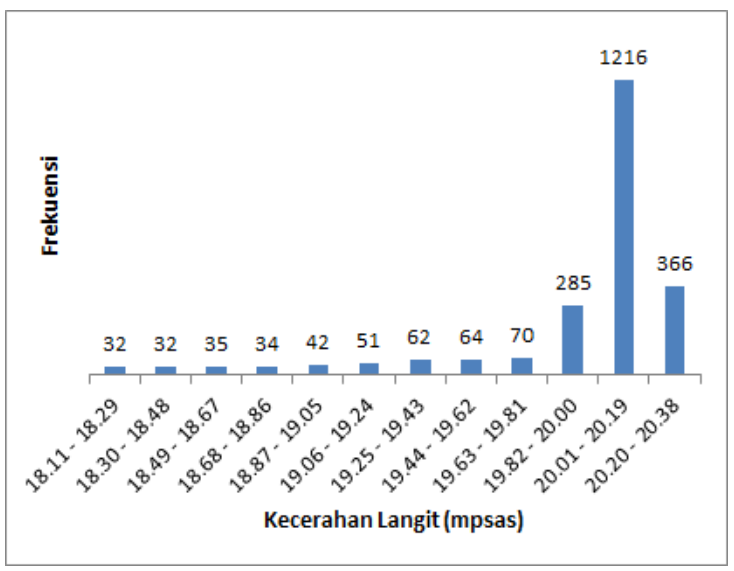

Gambar 7. Jumlah data kecerahan langit pada rentang tertentu tanggal 10 November 2018 di pantai Romantis

Gambar 8 menunjukkan jumlah data kecerahan langit pada rentang tertentu pada tanggal 11 November 2018 di pantai Romantis. Data kecerahan langit yang terbaca oleh SQM berada pada rentang 17,89 - 20,22 mpsas. Data kecerahan langit yang paling banyak terbaca oleh SQM berada pada rentang 19,99 - 20,19 mpsas dengan jumlah 933 data. Total data kecerahan langit yang dikumpulkan sebanyak 1896 data.

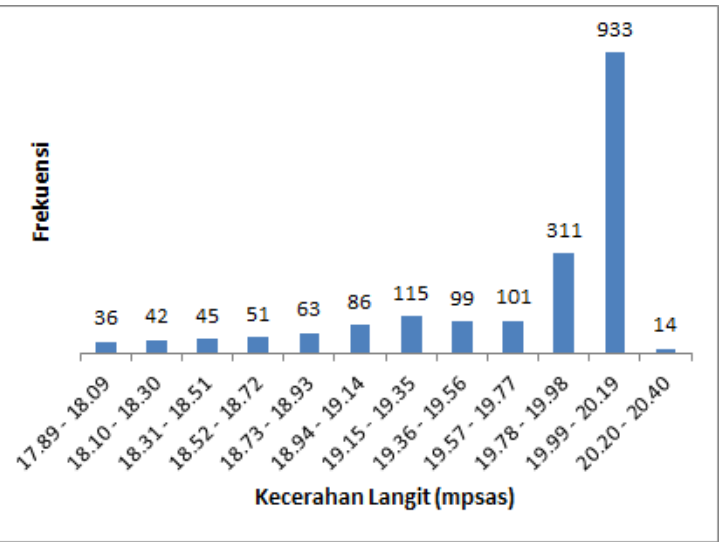

Gambar 8. Jumlah data kecerahan langit pada rentang tertentu pada tanggal 11 November 2018 di pantai Romantis

Gambar 9 menunjukkan jumlah data kecerahan langit pada rentang tertentu pada 
tanggal 12 November 2018 di pantai Romantis. Data kecerahan langit yang terbaca oleh SQM berada pada rentang 17,66 - 19,09 mpsas. Data kecerahan langit yang paling banyak terbaca oleh SQM berada pada rentang 18,92 - 19,05 mpsas dengan jumlah 639 data. Total data kecerahan langit yang dikumpulkan sebanyak 1501 data.

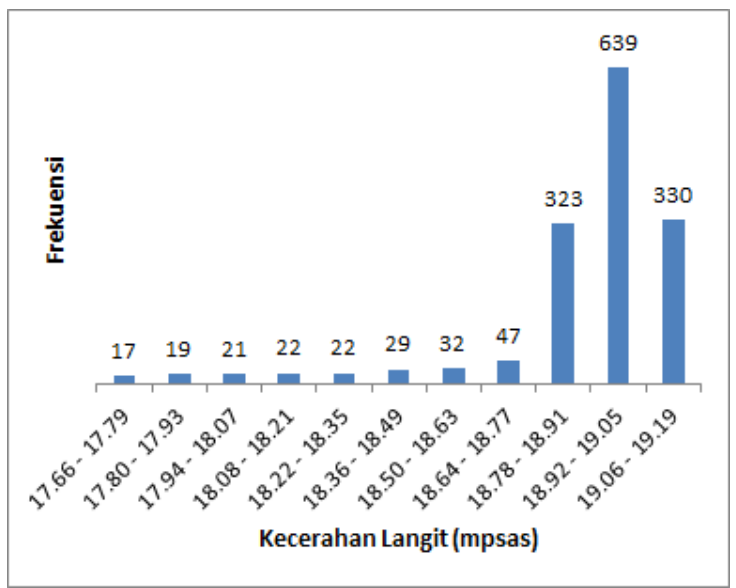

Gambar 9. Jumlah data kecerahan langit pada rentang tertentu pada tanggal 12 November 2018 di pantai Romantis

Gambar 10 menunjukkan jumlah data kecerahan langit pada rentang tertentu pada tanggal 13 November 2018 di pantai Romantis. Data kecerahan langit yang terbaca oleh SQM berada pada rentang 18,01 - 19,16 mpsas. Data kecerahan langit yang paling banyak terbaca oleh SQM berada pada rentang 19,01 - 19,10 mpsas dengan jumlah 672 data. Total data kecerahan langit yang dikumpulkan sebanyak 2220 data.

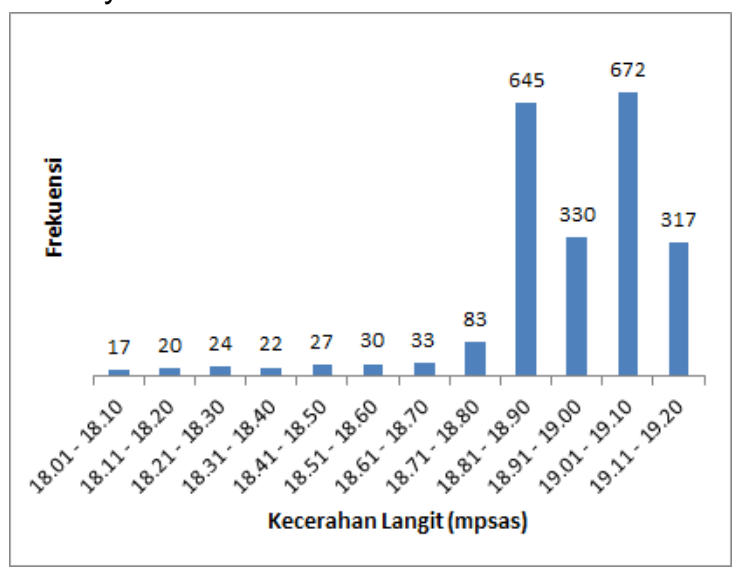

Gambar 10. Jumlah data kecerahan langit pada rentang tertentu tanggal 13 November
2018 di pantai Romantis

Nilai rata-rata NELM pada tanggal 10-13 November 2018 di pantai Romantis dapat dilihat pada tabel 3 .

Tabel 3. Nilai NELM di pantai Romantis

\begin{tabular}{ccc}
\hline Tanggal & $\begin{array}{c}\text { Kecerahan langit } \\
\text { maksimum (mpsas) }\end{array}$ & NELM \\
\hline $10 / 11 / 18$ & 20,27 & 5,67 \\
$11 / 11 / 18$ & 20,22 & 5,64 \\
$12 / 11 / 18$ & 19,09 & 4,84 \\
$13 / 11 / 18$ & 19,16 & 4,89 \\
\hline Rata-rata & 19,69 & 5,26 \\
\hline
\end{tabular}

\section{PEMBAHASAN}

Gambar 2, 3, 4 dan 5 merupakan frekuensi data kecerahan langit di OIF UMSU tanggal 10, 11, 12, dan 13 November 2018. Dari gambar 2, 3 , 4, dan 5 dapat dilihat bahwa kecerahan langit malam memiliki nilai yang bervariasi. Rentang nilai kecerahan langit yang paling rendah yang diperoleh SQM berada pada kelas yang paling kiri atau kelas ke-1, sementara rentang nilai kecerahan langit yang paling tinggi berada pada kelas yang paling kanan atau kelas ke-15.

Kecerahan langit yang terbaca oleh SQM pada gambar 2 berada pada rentang 16,41 18,34 mpsas. Data kecerahan langit yang paling banyak terbaca oleh SQM berada pada rentang 17,71 - 17,83 mpsas. Rentang tersebut berada pada kelas ke-11 dari 15 kelas dengan jumlah 1953 data dari total 9929 data.

Kecerahan langit yang terbaca oleh SQM pada gambar 3 berada pada rentang 17,38 18,65 mpsas. Data kecerahan langit yang paling banyak terbaca oleh SQM berada pada rentang 17,74 - 17,82 mpsas. Rentang tersebut berada pada kelas ke- 5 dari 15 kelas dengan jumlah 2178 data dari total 9930 data.

Kecerahan langit yang terbaca oleh SQM pada gambar 4 berada pada rentang 15,96 17,25 mpsas. Data kecerahan langit yang paling banyak terbaca oleh SQM berada pada rentang 16,50 - 16,58 mpsas. Rentang tersebut berada pada kelas ke-7 dari 15 kelas dengan jumlah 2000 data dari total 9926 data.

Kecerahan langit yang terbaca oleh SQM pada gambar 5 berada pada rentang 15,70 17,97 mpsas. Data kecerahan langit yang paling banyak terbaca oleh SQM berada pada rentang 16,50 - 16,65 mpsas. Rentang tersebut berada pada kelas ke- 6 dari 15 kelas dengan jumlah 3123 data dari total 9930 data.

Kecerahan langit di OIF UMSU yang memiliki frekuensi paling tinggi, tidak berada 
pada rentang nilai atau kelas yang paling tinggi. Hal ini dapat disebabkan karena beberapa faktor seperti awan dan lampu kendaraan di sekitar lokasi pengamatan. Keccerahan langit juga dapat dipengaruhi oleh kelembaban di lokasi pengamatan (Y. Pramudya et al., 2019).

Rata-rata kecerahan langit maksimum dan nilai NELM yang diperoleh di OIF UMSU adalah 18,05 mpsas dan 4,00. Berdasarkan skala Bortle, OIF UMSU berada pada daerah dengan kelas sembilan yaitu inner-city sky. Pada daerah yang berada di kelas ini, polusi cahaya sangat tinggi hingga seluruh langit terang benderang bahkan di zenit. Bintang-bintang yang membentuk rasi bintang yang familiar tidak terlihat. Rasi bintang redup seperti rasi bintang Cancer dan Pisces tidak dapat terlihat di daerah tersebut. Benda langit yang dapat dilihat menggunakan mata telanjang hanya Bulan, planet dan bintang terang seperti Sirius (Bortle, 2001).

Kecerahan langit yang terbaca oleh SQM pada gambar 7 berada pada rentang 18,11 20,27 mpsas. Data kecerahan langit yang paling banyak terbaca oleh SQM berada pada rentang 20,01 - 20,19 mpsas. Rentang tersebut berada pada kelas ke-11 dari 12 kelas dengan jumlah 1216 data dari total 2289 data.

Kecerahan langit yang terbaca oleh SQM pada gambar 8 berada pada rentang 17,89 20,22 mpsas. Data kecerahan langit yang paling banyak terbaca oleh SQM berada pada rentang 19,99 - 20,19 mpsas. Rentang tersebut berada pada kelas ke-11 dari 12 kelas dengan jumlah 933 data dari total 1896 data.

Kecerahan langit yang terbaca oleh SQM pada gambar 9 berada pada rentang 17,66 19,09 mpsas. Data kecerahan langit yang paling banyak terbaca oleh SQM berada pada rentang 18,92 - 19,05 mpsas. Rentang tersebut berada pada kelas ke-10 dari 11 kelas dengan jumlah 639 data dari total 1501 data.

Kecerahan langit yang terbaca oleh SQM pada gambar 10 berada pada rentang 18,01 19,16 mpsas. Data kecerahan langit yang paling banyak terbaca oleh SQM berada pada rentang 19,01 - 19,10 mpsas. Rentang tersebut berada pada kelas ke-11 dari 12 kelas dengan jumlah 672 data dari total 2220 data.

Kecerahan langit di pantai Romantis yang memiliki frekuensi paling tinggi, berada pada rentang nilai atau kelas yang tinggi. Gangguan awan dan lampu kendaraan sedikit sehingga nilai kecerahan langit yang diperoleh lebih stabil dibandingkan dengan di OIF UMSU.

Rata-rata kecerahan langit maksimum dan nilai NELM yang diperoleh di pantai Romantis adalah 19,69 mpsas dan 5,26. Berdasarkan skala Bortle, pantai Romantis berada pada daerah dengan kelas keenam yaitu bright suburban sky. Pada daerah yang berada di kelas ini, polusi cahaya membuat langit $35^{\circ}$ di atas horizon bersinar putih keabu-abuan. Cahaya zodiak tidak dapat dilihat terlihat bahkan pada malam terbaik sekalipun. Galaksi Bima Sakti hanya dapat terlihat di zenit meskipun tidak terlalu jelas (Bortle, 2001).

\section{PENUTUP}

Kecerahan langit di Medan banyak dipengaruhi oleh awan dan lampu kendaraan di sekitar sehingga nilai yang diperoleh tidak stabil. Hal ini dapat dilihat dari frekuensi kecerahan langit paling tinggi berada pada rentang nilai kecerahan langit yang rendah. Sementara kecerahan langit di Serdang Bedagai lebih stabil dikarenakan gangguan awan dan lampu kendaraan lebih sedikit dibandingkan dengan di Medan. Hal ini dapat dilihat dari frekuensi kecerahan langit paling tinggi berada pada rentang nilai kecerahan langit yang tinggi.

Nilai rata-rata kecerahan langit yang diperoleh di Medan sebesar 18,05 mpsas dan nilai NELM sebesar 4,00. Berdasarkan skala Bortle, Medan berada pada daerah dengan kelas kesembilan yaitu inner-city sky. Pada daerah yang berada di kelas ini, polusi cahaya sangat tinggi hingga seluruh langit terang benderang bahkan di zenit. Benda langit yang dapat dilihat menggunakan mata telanjang hanya Bulan, planet dan bintang terang. Sementara nilai rata-rata kecerahan langit yang diperoleh di Serdang Bedagai sebesar 19,69 mpsas dan nilai NELM sebesar 5,26. Berdasarkan skala Bortle, Serdang Bedagai berada pada daerah dengan kelas keenam yaitu bright suburban sky. Pada daerah yang berada di kelas ini, polusi cahaya membuat langit $35^{\circ}$ di atas horizon bersinar putih keabuabuan. Cahaya zodiak tidak dapat dilihat terlihat bahkan pada malam terbaik sekalipun. Galaksi Bima Sakti hanya dapat terlihat di zenit meskipun tidak terlalu jelas.

Pengambilan data dalam penelitian hanya dilakukan masing-masing di satu lokasi untuk mewakilkan Medan dan Serdang Bedagai. Dengan pengambilan data di lokasi yang lebih banyak, hasil yang diperoleh akan lebih akurat.

\section{REFERENSI}

Bortle, J. E. (2001). Introducing the Bortle DarkSky Scale. Sky \& Telescope, 101(2), 126130.

Butar-Butar, A. J. R., Raisal, A. Y., \& Pramudya, 
Y. (2020). Effect of the total lunar eclipse of 28 July 2018 on the night sky brightness at the Observatorium IImu Falak Universitas Muhammadiyah Sumatera Utara. Journal of Physics: Conference Series, 1523(1), 1-6. https://doi.org/10.1088/17426596/1523/1/012005

Cinzano, P. (2005). Night sky photometry with sky quality meter. ISTIL Internal Report, $1-14$.

Herdiwijaya, D, \& Arumaningtyas, E. P. (2011). Pengukuran kecerlangan langit arah zenith di bandung dan cimahi dengan menggunakan sky quality meter. Prosiding Seminar Himpunan Astronomi Indonesia., 6-8.

Herdiwijaya, Dhani. (2016). Sky brightness and twilight measurements at Jogyakarta city, Indonesia. Journal of Physics: Conference Series, 771(1), 1-4. https://doi.org/10.1088/17426596/771/1/012033

Lyytimäki, J., Tapio, P., \& Assmuth, T. (2012). Unawareness in environmental protection: The case of light pollution from traffic. Land Use Policy, 29(3), 598-604. https://doi.org/10.1016/j.landusepol.2011. 10.002

Noor, L. A. H., \& Hamdani, F. F. R. S. (2018). The dawn sky brightness observations in the preliminary shubuh prayer time determination. Qudus International Journal of Islamic Studies, 6(1), 25-37. https://doi.org/10.21043/qijis.v1i1.2870

Pramudya, Y., Budi, K. S., Okimustava, \& Muchlas. (2019). Preliminary study on relation between temperature, humidity and Night Sky Brightness in Yogyakarta. Journal of Physics: Conference Series, 1231(1), $1-7$. https://doi.org/10.1088/1742$6596 / 1231 / 1 / 012004$

Pramudya, Yudhiakto, \& Arkanuddin, M. (2016). The sky brightness measurement during the 2016 solar eclipse in Ternate. Journal of Physics: Conference Series, 771(1), 1-4. https://doi.org/10.1088/17426596/771/1/012013

Raisal, A. Y., Hidayat, M., Hermawan, L., \& Rakhmadi, A. J. (2021). The Effect of the Installation Angle of the Sky Quality Meter on the Night Sky Brightness and the
Beginning of the Fajr Prayer Time. Indonesian Review of Physics, 3(2), 3539. https://doi.org/10.12928/irip.v3i2.2074

Raisal, A. Y., Pramudya, Y., Okimustava, O., \& Muchlas, M. (2017). The moon phases influence on the beginning of astronomical dawn determination in Yogyakarta. International Journal of Science and Applied Science: Conference Series, 2(1), 1-7.

https://doi.org/10.20961/ijsascs.v2i1.166 64

Rajkhowa, R. (2014). Light Pollution and Impact of Light Pollution. International Journal of Science and Research (IJSR), 3(10), 861-867. www.ijsr.net

Unihedron. (2020). Unihedron SQM-LU-DL Opertor's Manual. Unihedron. http://unihedron.com/projects/darksky/cd/ SQM-LU-DL/SQM-LUDL_Users_manual.pdf 